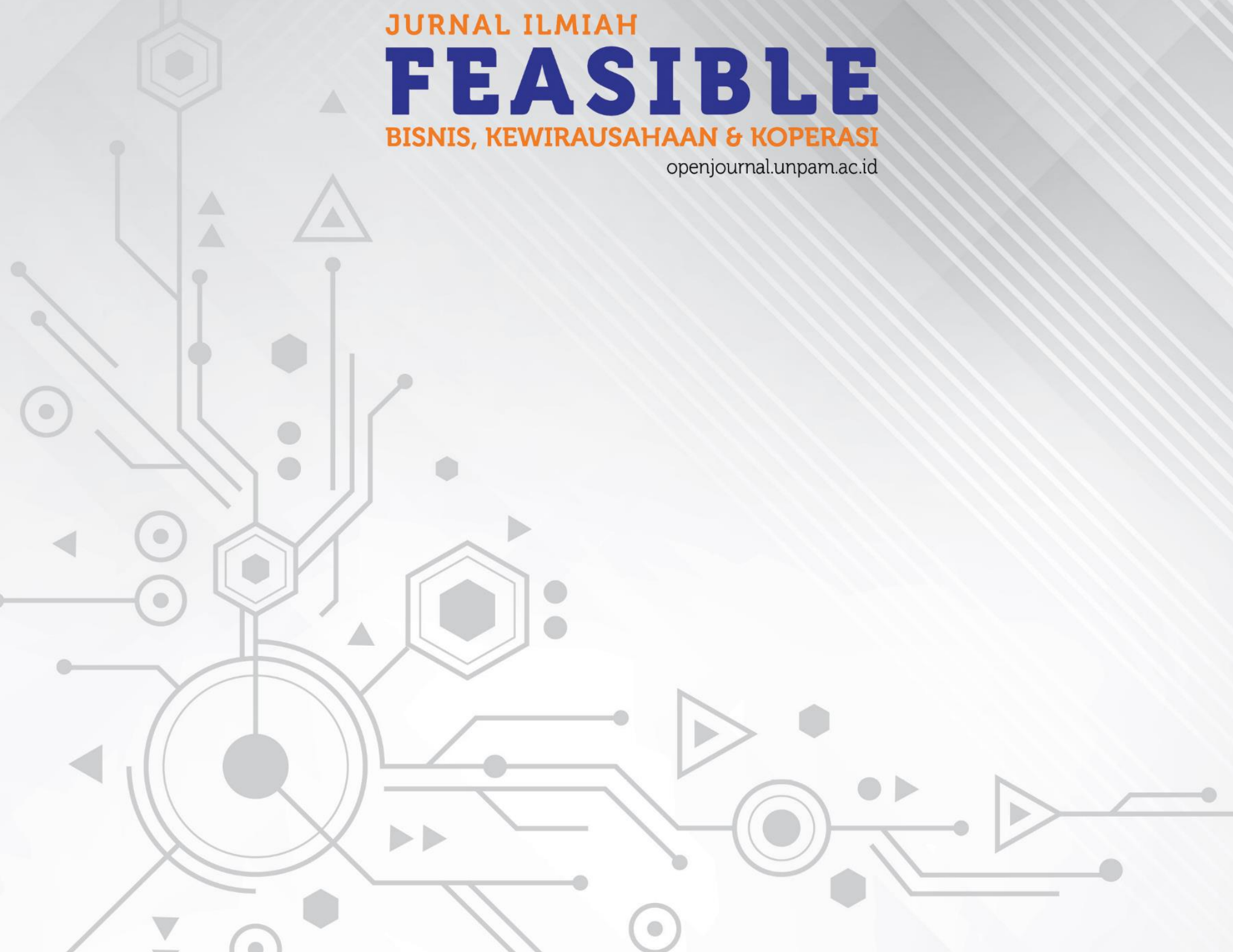





\title{
PENGARUH PERPUTARAN KAS DAN PERPUTARAN PIUTANG TERHADAP RETUN ON EQUITY (ROE) PADA PT INDOFOOD SUKSES MAKMUR TBK PERIODE TAHUN 2009-2017
}

\author{
Supatmin \\ Fakultas Ekonomi, Universitas Pamulang \\ dosen01767@unpam.ac.id
}

\begin{abstract}
Abstrak
Tujuan penelitian ini untuk mengetahui pengaruh perputaran kas dan perputaran piutang terhadap Return on Equity (ROE) pada PT Indofood Sukses Makmur Tbk Periode 2009-2017. Metode penelitian yang digunakan kuantitatif dengan pendekatan deskriptif. Data yang digunakan merupakan data sekunder dari Indonesia Capital Directory Market. Teknik analisis menggunakan analisis regresi linear sederhana, regresi linier berganda dan uji hipotesis pada level of significance 5\%. Hasil penelitian secara simultan rasio profitabilitas perputaran kas dan perputaran piutang berpengaruh positif dan signifikan terhadap Return on Equity (ROE). Sedangkan secara parsial perputaran kas tidak berpengaruh signifikan terhadap Return on Equity (ROE) dan perputaran piutang berpengaruh positif signifikan terhadap Return on Equity. Dengan tingkat konstribusi variabel perputaran kas dan perputaran piutang sebesar $72 \%$.
\end{abstract}

Kata Kunci: Perputaran Kas, Perputaran Piutang, dan Return on Equity.

\begin{abstract}
The purpose of this study was to determine the effect of cash turnover and accounts receivable turnover on Return on Equity (ROE) at PT Indofood Sukses Makmur Tbk Period 2009-2017. The research method used is quantitative with a descriptive approach. The data used is secondary data from the Indonesia Capital Directory Market. The analysis technique uses simple linear regression analysis, multiple linear regression and hypothesis testing at the level of significance of $5 \%$. The results of the study simultaneously profitability ratios of cash turnover and accounts receivable turnover have a positive and significant effect on Return on Equity (ROE). While partially cash turnover has no significant effect on Return on Equity (ROE) and accounts receivable turnover has a significant positive effect on Return on Equity. With the variable contribution rate of cash turnover and accounts receivable turnover of $72 \%$.
\end{abstract}

Keywords: Cash Turnover, Receivable Turnover, and Return on Equity.

\section{PENDAHULUAN}

\section{Latar Belakang}

Kemajuan teknologi saat ini telah berpengaruh besar terhadap cara perusahaan dalam menjalankan kegiatan operasionalnya agar senantiasa semakin efisien dan efektif. Perusahaan dituntut untuk selalu selangkah lebih maju dari para pesaingnya agar dapat mencapai tujuan perusahaan, yaitu menghasilkan laba 
JURNAL ILMIAH FEASIBLE: Bisnis, Kewirausahaan \& Koperasi, Vol.2.No.1 Februari 2020: 11-26

sebesar-besarnya demi mempertahankan kelangsungan hidupnya seraya memperbesar skala usahanya.

Agar perusahaan bertambah besar, maka perusahaan harus berkembang untuk dapat mengikuti dan memenuhi kebutuhan pasar yang berubah-ubah. Dengan bertambah besarnya perusahaan, perusahaan dituntut semakin lihai pula dalam mengelola dana yang tersedia untuk menjalankan akitivitas operasional perusahaan. Dana yang diinvestasikan untuk menjalankan aktivitas operasional sehari-hari inilah yang dinamakan modal kerja.

Modal kerja harus senantiasa dikelola agar tidak terlalu kecil maupun terlalu besar jumlahnya. Jika jumlahnya terlalu kecil, perusahaan akan menghadapi kondisi illikuid yaitu kondisi dimana perusahaan kesulitan untuk memenuhi kewajiban lancarnya yang disebabkan oleh tidak tersedianya dana yang cukup untuk melunasi utang jangka pendek perusahaan yang telah jatuh tempo. Sementara itu, jika jumlah modal kerja terlalu besar, maka hal terebut bisa teradi adanya dana yang menganggur. Dana yang menganggur berarti mengurangi laba perusahaaan karena dana tersebut seharusnya dapat digunakan dalam berbagai macam kepentingan pengembangan usaha maupun untuk membiayai investasi jangka pendek perusahaan.

Setiap perusahaan harus menerapkan sistem manajemen yang sesuai dengan prosedur agar dapat berkembang dan menjalankan usahanya dengan efektif. Manajemen tersebut digunakan untuk mengatur dan mengontrol kegiatan operasional perusahaan. Keberhasilan manajemen dalam mengelola perusahaan pembiayaan adalah dengan melihat seberapa efektif penggunaan kas dan piutang untuk mendapat profitabilitas. Setiap perusahaan bertujuan untuk memperoleh profitabilitas. Salah satu yang dapat digunakan untuk mengukur tingkat profitabilitas adalah Return on Equity (ROE).

Return on Equity (ROE) merupakan rasio untuk mengukur laba bersih sesudah pajak dengan modal sendiri. Rasio ini menitikberatkan pada bagaimana efisiensi operasi perusahaan ditranslasi menjadi keuntungan bagi para pemilik perusahaan. Rasio ini juga dapat menjadi suatu indikator seberapa besar perusahaan untuk memberiakan dividen untuk para pemegang saham pada PT Indofood Sukses Makmur Tbk dalam beberapa tahun ini selalu terjadi fluktuasi yang cenderung mengalami penurunan terhadap para pemegang saham atau keuntungan dividen sehingga mempengaruhi para investor dan juga calon investor yang ingin menanamkan modalnya pada perusahaan tersebut.

Beberapa faktor yang mempengaruhi penurunan persentase dalam pengembalian modal sendiri (ROE) yaitu perputaran kas dan perputaran piutang. Kas dan piutang memiliki pengaruh yang tinggi terhadap laba sehingga perlu penanganan yang efektif dan efisien. 
JURNAL ILMIAH FEASIBLE: Bisnis, Kewirausahaan \& Koperasi, Vol.2.No.1 Februari 2020: 11-26

Perputaran kas merupakan periode berputarnya kas yang dimulai saat kas diinvestasikan dalam komponen modal kerja sampai saat kembali menjadi kas-kas sebagai unsur modal kerja yang paling tinggi likuiditasnya. Menurut teori (Riyanto, 2011: 95) "semakin tinggi perputaran kas akan semakin baik, karena ini berarti semakin tinggi efisiensi penggunaan kasnya dan keuntungan yang diperoleh akan semakin besar”.

\begin{tabular}{|c|c|c|c|c|c|c|c|}
\hline \multicolumn{8}{|c|}{$\begin{array}{l}\text { Tabel 1.1. Perkembangan Perputaran Kas } \\
\text { Periode 2009-2017 (Dalam Jutaan Rupiah) }\end{array}$} \\
\hline \multirow{2}{*}{ Tahun } & \multirow{2}{*}{ Total Kas } & \multirow{2}{*}{$\begin{array}{c}\text { Rata-rata } \\
\text { Kas }\end{array}$} & \multirow{2}{*}{$\begin{array}{c}\text { Penjuan } \\
\text { Bersih }\end{array}$} & \multirow{2}{*}{$\begin{array}{l}\text { Perputaran } \\
\text { kas (kali) }\end{array}$} & \multicolumn{3}{|c|}{ Keterangan } \\
\hline & & & & & Selisih & (\%) & - \\
\hline 2009 & $8,746,037$ & $4,373,019$ & $37,140,830$ & 8,49 & & & \\
\hline 2010 & $14,803,820$ & $7,401,910$ & $38,403,360$ & 5.19 & -3.30 & $38.9 \%$ & $\underline{\text { Turun }}$ \\
\hline 2011 & $23,335,188$ & $11,667,594$ & $45,332,256$ & 3.89 & -1.30 & $25.1 \%$ & Turun \\
\hline 2012 & $26,223,827$ & $13,111,913$ & $50,059,427$ & 3.82 & -0.07 & $-1.7 \%$ & Turun \\
\hline 2013 & $26,736,340$ & $13,368,170$ & $57,731,998$ & 4.32 & 0.50 & $13.1 \%$ & Naik \\
\hline 2014 & $27,676,515$ & $13,838,257$ & $63,594,452$ & 4.60 & 0.28 & $6.4 \%$ & Naik \\
\hline 2015 & $27,119,846$ & $13,559,923$ & $64,061,947$ & 4.72 & 0.13 & $2.8 \%$ & Naik \\
\hline 2016 & $26,324,277$ & $13,162,138$ & $66,750,317$ & 5.07 & 0.35 & $7.3 \%$ & Naik \\
\hline 2017 & $27,052,234$ & $13,526,117$ & $70,186,618$ & 5.19 & 0.12 & $2.3 \%$ & Naik \\
\hline
\end{tabular}

Sumber: Laporan neraca dan laba rugi PT.Indofood Sukses Makmur, Tbk

Berdasarkan di atas dapat diketahui bahwa perputaran kas PT Indofood Sukses Makmur Tbk dari tahun 2009 sampai 2017 mengalami peningkatan dan juga penurunan yang di sebut fluktuasi. Perputaran kas tertinggi yaitu tahun 2009 dan 2017 sebesar 8,49 kali sedangkan terendah tahun 2012 yaitu sebesar 3,82 kali. Perputaran kas pada PT Indofood Skses Makmur Tbk dari tahun 2009 sampai dengan 2017 cenderung berfluktuatif. Perpuran kas tahun 2009 sebesar 8,49 kali menurun pada tahun 2010 sebesar 5,19 kali dan menurun lagi pada tahun 2011 yaitu sebesar 3,89 kali. Kemudian di tahun 2012 terus menurun menjadi 3,82 kali, Pada tahun 2013 naik menjadi kali menjadi 4,32 kali, tahun 2014 meningkat kembali menjadi 4,60 kali dan di tahun 2015 meningkat lagi menjadi 4,72 kali. kemudian menurun di tahun 2016 meningkat lagi menjadi 5,07 kali dan terus mengalami kenaikan di tahun 2017 menjadi 5,19 kali.

Menurut (Hery, 2013: 181) "Piutang adalah sejumlah tagihan yang akan diterima oleh perusahaan umumnya dalam bentuk kas dari pihak lain. Untuk itu pengelolaan piutang memerlukan perencanaan yang matang, mulai dari penjualan kredit yang menimbulkan piutang sampai menjadi kas. Investasi yang terlalu besar dalam piutang bisa menimbulkan lambatnya perputaran piutang, sehingga semakin kecil pula kemampuan perusahaan dalam meningkatkan volume penjualan dan mengakibatkan semakin kecilnya kesempatan yang dimiliki perusahaan untuk menghasilkan keuntungan atau laba yang dihasilkan suatu perusahaan sehingga bisa mengakibatkan kurang efektip dan efisien".

\begin{tabular}{|c|c|c|c|c|c|c|c|}
\hline \multicolumn{8}{|c|}{$\begin{array}{c}\text { Tabel 1.2. Perkembangan Perputaran Piutang } \\
\text { Periode 2009-2017 (Dalam Jutaan Rupiah) }\end{array}$} \\
\hline \multirow[b]{2}{*}{ Tahun } & \multirow{2}{*}{$\begin{array}{c}\text { Total } \\
\text { Piutang }\end{array}$} & \multirow{2}{*}{$\begin{array}{c}\text { Rata-Rata } \\
\text { Piutang }\end{array}$} & \multirow{2}{*}{$\begin{array}{c}\text { Penjualan } \\
\text { Bersihh }\end{array}$} & \multirow{2}{*}{$\begin{array}{c}\text { Perputaran } \\
\text { Piutang } \\
\text { (kali) }\end{array}$} & \multicolumn{3}{|c|}{ Ketengan } \\
\hline & & & & & Selisith & (\%) & \\
\hline 2009 & $4,365,766$ & $2,182,883$ & $38,799,279$ & 17,77 & 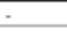 & 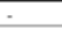 & - \\
\hline 2010 & $4,356,649$ & $2,178,324$ & $38,403,360$ & 17.63 & -0.01 & $-0.07 \%$ & Turun \\
\hline 2011 & $5,312,286$ & $2,656,143$ & 32,256 & 17.07 & -0.56 & $-3.19 \%$ & Turun \\
\hline 2012 & $5,956,530$ & $2,978,265$ & $50,059,427$ & 16.81 & -0.26 & $-1.52 \%$ & Turun \\
\hline 2013 & $7,546,173$ & $3,773,086$ & $57,731,998$ & 15.30 & -1.51 & $-8.97 \%$ & Turun \\
\hline 2014 & $8,071,766$ & $4,035,883$ & $63,594,452$ & 15.76 & 0.46 & $3.41 \%$ & Naik \\
\hline 2015 & $7,863,222$ & $3,931,611$. & $64,061,947$ & 16.29 & 0.54 & $3.41 \%$ & Naik \\
\hline 2016 & $8,971,088$ & $4,485,544$ & $66,750,317$ & 14.88 & -1.41 & $-8.67 \%$ & Turun \\
\hline 2017 & $9,769,869$ & $4,884,934$ & $70,186,618$ & 14.37 & -0.51 & $-3.45 \%$ & Turun \\
\hline
\end{tabular}

Sumber: Laporan neraca dan laba rugi PT.Indofood Sukses Makmur, Tbk

Berdasarkan tabel di atas diketahui bahwa perputaran piutang pada PT 
JURNAL ILMIAH FEASIBLE: Bisnis, Kewirausahaan \& Koperasi, Vol.2.No.1 Februari 2020: 11-26

Indofood Skses Makmur Tbk dari tahun 2009 sampai dengan 2017 cenderung berfluktuatif. Perpuran piutang tertinggi yaitu tahun 2009 sebesar 17,77 kali sedangkan paling rendah yaitu pada tahun 2017 sebesar 14,37 kali. Perputaran piutang di tahun 2009 yaitu sebesar 17,77 menurun di tahun 2010 yaitu 17,63 kali dan menurun lagi di tahun 2011 sebesar 17,07, kemudian menurun lagi di tahun 2012 menjadi 16,81 kali, turun lagi di tahun 2013 menjadi 15,30, kali dan naik lagi di tahun 2014 menjadi 15,76 kali, kemudian terus naik di tahun 2015 menjadi 16,29 .Sedangkan di tahun 2016 mengalami penurunan lagi menjadi 14,88 dan terus menurun di tahun 2017 menjadi 14,37 kali.

Kedua komponen tersebut, yaitu Perputaran kas dan perputaran piutang dapat mempengaruhi tingkat profitabilitas. Profitabilitas merupakan kemampuan perusahaan memperoleh laba yang berhubungan dengan penjualan, total aktiva maupun modal. Profitabilitas dapat digunakan sebagai tolak ukur untuk menilai keberhasilan dari suatu perusahaan dalam menjalankan usahanya dan juga dapat digunakan sebagai tolak ukur dalam menilai prospek return dari modal yang akan ditanamkan oleh investor.

Tabel 1.3. Perkembangan Return on Equity (ROE) Periode 2009-2017 (Dalam Jutaan Rupiah)

\begin{tabular}{|c|c|c|c|c|c|c|}
\hline \multirow{2}{*}{ No } & \multirow{2}{*}{ Tahun } & \multirow{2}{*}{$\begin{array}{c}\text { Laba Bersih } \\
\text { Setelah Pajak }\end{array}$} & \multirow{2}{*}{ Total Equity } & \multirow{2}{*}{ ROE } & \multicolumn{2}{|c|}{ Keterangn } \\
\hline & & & & & (\%) & \\
\hline 1 & 2009 & $2,075,861$ & $10,155,495$ & $20,43 \%$ & - & - \\
\hline 2 & 2010 & $3,934,808$ & $24,852,838$ & $15.83 \%$ & $-4.61 \%$ & Turun \\
\hline 3 & 2011 & $4,891,673$ & $31,610,225$ & $15.47 \%$ & $-0.36 \%$ & Turun \\
\hline
\end{tabular}

\begin{tabular}{|c|c|c|c|c|c|c|}
\hline \multirow{2}{*}{ No } & \multirow{2}{*}{ Tahun } & $\begin{array}{c}\text { Laba Bersih } \\
\text { Setelah Pajak }\end{array}$ & Total Equity & ROE & \multicolumn{2}{|c|}{ Keterangn } \\
\cline { 6 - 7 } & & & $\mathbf{9})$ & \\
\hline 4 & 2012 & $4,779,446$ & $34,142,674$ & $14.00 \%$ & $-1.48 \%$ & Turun \\
\hline 5 & 2013 & $3,416,635$ & $38,373,129$ & $8.90 \%$ & $-5.09 \%$ & Turun \\
\hline 6 & 2014 & $5,146,323$ & $41,228,376$ & $12.48 \%$ & $3.58 \%$ & Naik \\
\hline 7 & 2015 & $3,709,501$ & $43,121,593$ & $8.60 \%$ & $-3.88 \%$ & Turun \\
\hline 8 & 2016 & $5,266,906$ & $43,941,423$ & $11.99 \%$ & $3.38 \%$ & Naik \\
\hline 9 & 2017 & $5,145,063$ & $46,756,724$ & $11.00 \%$ & $-0.99 \%$ & Turun \\
\hline
\end{tabular}

Sumber: Laporan neraca dan laba rugi PT.Indofood Sukses Makmur, Tbk

Berdasarkan latar belakang di atas maka penulis tertarik untuk melakukan penelitian dengan judul "Pengaruh Perputaran Kas dan Perputaran Piutang Terhadap Retun on Equity (ROE) Pada PT Indofood Sukses Makmur Tbk, Periode tahun 2009-2017".

\section{Kajian Literatur}

\section{Perputaran Kas}

Perputaran kas merupakan kemampuan kas untuk menghasilkan pendapatan sehingga dapat dilihat berapa kali uang kas berputar dalam satu periode tertentu. Semakin tinggi tingkat perputaran kas berarti semakin efisien tingkat penggunaan kasnya dan sebaliknya semakin rendah tingkat perputarannya semakin tidak efisien, karena semakin banyak uang yang berhenti atau tidak dipergunakan.

Menurut (Bambang, 2011: 95) "Perputaran kas adalah perbandingan antara penjualan dengan jumlah kas ratarata. Tingkat perputaran kas merupakan ukuran efisiensi penggunaan kas yang dilakukan oleh perusahaan. Karena tingkat perputaran kas menggambarkan kecepatan arus kas kembalinya kas yang telah ditanamkan di dalam modal kerja. Dalam 
JURNAL ILMIAH FEASIBLE: Bisnis, Kewirausahaan \& Koperasi, Vol.2.No.1 Februari 2020: 11-26

mengukur tingkat perputaran kas, sumber masuknya kas yang telah tertanam dalam modal kerja adalah berasal dari aktivitas operasional perusahaan”. Menurut (Wild, Subramanyan, \& Hasley, 2005: 42) perputaran kas dalam satu periode dapat dihitung dengan rumus:

Perputaran Kas $=\frac{\text { Penjualan Bersih }}{\text { Rata-rata Kas }}$

Semakin tinggi tingkat perputaran kas berarti semakin cepat kembalinya kas masuk pada perusahaan. Dengan demikian kas akan dapat dipergunakan kembali untuk membiayai kegiatan operasional sehingga tidak mengganggu kondisi keuangan perusahaan.

\section{Perputaran Piutang}

Perputaran piutang merupakan suatu ukuran yang menunjukkan berapa kali suatu piutang perusahaan telah diputar kembali menjadi kas selama tahun buku tersebut. Ini sering digunakan bersama dengan analisis modal kerja, karena aliran yang lancar dari piutang menjadi kas merupakan indikator penting dari kualitas modal kerja perusahaan dan merupakan hal kritis dalam kemampuan perusahaan beroperasi.

Menurut (Kasmir, 2015: 176) yang menyatakan bahwa "perputaran piutang merupakan rasio yang digunakan untuk mengukur berapa lama penagihan piutang selama satu periode atau berapa kali dana yang ditanam dalam piutang ini berputar dalam satu periode”. Indikator untuk perputaran piutang adalah penjualan dibagi rata-rata piutang.
Perputaran Piutang $=\frac{\text { Penjualan Bersih }}{\text { Rata-rata Piutang }}$

\section{Profitabilitas}

Rasio profitabilitas merupakan aspek fundamental perusahaan, karena selain memberikan daya tarik yang besar bagi investor yang akan menanamkan dananya pada perusahaan juga sebagai alat ukur terhadap efektivitas dan effisiensi penggunaan semua sumber daya yang ada di dalam proses operasional perusahaan.

Menurut (Kasmir, 2016: 196) "Rasio profitabilitas yakni Rasio yang menilai kemampuan perusahaan dalam mencari keuntungan." Rasio ini dapat juga memberikan ukuran tingkat efektivitas manajemen suatu perusahaan. Hal ini ditunjukkan oleh adanya laba yang dihasilkan dari penjuaan dan pendapatan investasi. Inti dari penggunaan rasio ini adalah untuk menunjukkan efisiensi perusahaan.

\section{Tujuan dan Manfaat Rasio Profitabilitas}

Rasio profitabilitas memiliki tujuan dan manfaat tidak hanya bagi pihak internal, tetapi juga bagi pihak ekternal atau diluar perusahaan. Menurut (Kasmir, 2015: 197) tujuan dan manfaat penggunaan rasio profitabilitas adalah sebagai berikut:

a. "Untuk mengukur atau menghitung laba yang diperoleh perusahaan dalam satu periode tertentu.

b. Untuk menilai posisi laba perusahaan tahun sebelumnya dengan tahun sekarang. 
c. Untuk menilai perkembangan laba dari waktu ke waktu.

d. Untuk menilai besarnya laba bersih sesudah pajak dengan modal sendiri.

e. Untuk mengukur produktivitas seluruh dana perusahaan yang digunakan baik modal pinjaman maupun modal sendiri.

f. Untuk mengukur produktivitas dari seluruh dana perusahaan yang digunakan baik modal sendiri.”

Adapun manfaat yang diperoleh dari rasio profitabilitas adalah untuk:

a. "Mengetahui besarnya tingkat laba yang diperoleh perusahaan dalam satu periode.

b. Mengetahui posisi laba perusahaan tahun sebelumnya dengan tahun sekarang.

c. Mengetahui perkembangan laba dari waktu ke waktu.

d. Mengetahui besarnya laba bersih sesudah pajak dengan modal sendiri.

e. Mengetahui produktivitas dari seluruh dana perusahaan yang digunakan baik modal pinjaman maupun modal sendiri”.

\section{Return on Equity (ROE)}

Menurut (Kasmir, 2015: 104) "return on equity (ROE) merupakan rasio yang digunakan untuk mengukur laba bersih sesudah pajak dengan modal sendiri. Rasio ini menunjukkan efisiensi penggunaan modal sendiri”. Semakin tinggi rasio ini, semakin baik. Artinya posisi pemilik perusahaan semakin kuat, demikian pula sebaliknya.

$R O E=\frac{\text { Laba Bersih sesudah Pajak }}{\text { Total Equity }}$

Faktor-faktor yang Mempengaruhi return on equity (ROE) adalah menunjukkan kesuksesan manajemen dalam memaksimalkan pengembalian pada pemegang saham, semakin tinggi rasio ini akan semakin baik karena memberikan tingkat pengembalian yang lebih besar pada pemegang saham. Untuk meningkatkan ROE terdapat faktor-faktor yang mempengaruhinya. Untuk meningkatkan tingkat pengembalian ekuitas dapat diperoleh dengan cara sebagai berikut :

a. Meningkatkan penjualan tanpa meningkatkan beban dan biaya secara proporsional.

b. Mengurangi harga pokok penjualan atau beban operasi perusahaan.

c. Meningkatkan penjualan secara relatif atas dasar nilai aktiva, baik dengan meningkatkan penjualan atau mengurangi jumlah investasi pada aktiva penjualan.

Meningkatkan penggunaan utang secara relatif terhadap ekuitas, sampai titik yang tidak membahayakan kesejahteraan keuangan perusahaan.

\section{METODE}

\section{Sifat Penelitian}

Metode penelitian yang digunakan adalah metode penelitian kuantitatif dengan pendekatan deskriptif. Pengertian metode kuantitatif menurut (Sugiono, 2011: 8), menyatakan bahwa: Metode penelitian yang berlandaskan pada filsafat positivisme, 
JURNAL ILMIAH FEASIBLE: Bisnis, Kewirausahaan \& Koperasi, Vol.2.No.1 Februari 2020: 11-26

digunakan untuk meneliti pada populasi atau sampel tertentu, pengumpulan data menggunakan instrument penelitian, analisis data bersifat kuantutatif atau statistik, dengan tujuan untuk menguji hipotesis yang telah ditetapkan." Pendekatan deskriptif menurut (Sugiono, 2011: 35), adalah metode penelitian deskriptif ini dilakukan untuk mengetahui keberadaan variabel mandiri, baik hanya pada sat variabel atau lebih (variabel yang berdiri sendiri atau variabel bebas) tanpa membuat perbandingan variabel itu sendiri dan mencari hubungan dengan variabel lain.

\section{Waktu dan Tempat}

Data yang di ambil dari tahun 2009 sampai dengan tahun 2017, sedangkan objek penelitian ini adalah laporan keuangan yang meliputi laporan laba rugi dan neraca. Waktu penelitian dilakukan terhitung dari bulan Juli sampai dengan November 2018. Perusahaan yang menjadi objek penelitian ini adalah PT Indofood Sukses Makmur Tbk di Jakarta dengan alamat Sudirman Plaza, Indofood Tower, Lantai 27, Jl. Jend. Sudirman Kav. 76 - 78, Jakarta, Indonesia.

\section{Populasi dan Sampel}

Menurut (Sugiono, 2011: 80), "populasi adalah wilayah generalisasi yang terdiri atas obyek dan subyek yang mempunyai kualitas dan karakteristik tertentu yang ditetapkan oleh peneliti untuk dipelajari dan kemudian ditarik kesimpulannya”. Sedangkan yang dimaksud "sampel adalah bagian dari jumlah dan karakteristik yang dimiliki oleh populasi tersebut” (Sugiono, 2014: 81). Populasi dalam penelitian ini adalah keseluruhan laporan keuangan PT Indofood Sukses Makmur Tbk. Sampel yang digunakan berupa neraca dan laporan labarugi dari periode 2009- 2017.

\section{Analisis Data}

Teknik analisis data yang digunakan penulis adalah deskriptif kuantitatif yaitu cara memperoleh data berupa hasil perhitungan dalam bentuk angka-angka mutlak atau absolute dengan menggunakan rumus matematis. Motode analisis yang digunakan meliputi: uji asumsi klasik, uji regresi linier, koefisen korelasi, koefisien determinasi, uji hipotesis.

\section{HASIL dan PEMBAHASAN}

\section{Hasil}

Berdasarkan data yang diperoleh, perputaran kas, perputaran piutang dan Return on Equity (ROE) dapat disimpulkan sebagai berikut:

Tabel 1.4. Hasil Pengolahan Perputaran Kas, Perputaran Piutang, dan Return on Equity (ROE)

(Dalam Jutaan Rupiah)

\begin{tabular}{|c|c|c|c|}
\hline Tahun & $\begin{array}{c}\text { Perputaran } \\
\text { kas }\end{array}$ & $\begin{array}{c}\text { Perputaran } \\
\text { Piutang }\end{array}$ & ROE \\
\hline $\mathbf{2 0 0 9}$ & 8.49 & 17.62 & $20.4 \%$ \\
\hline $\mathbf{2 0 1 0}$ & 5.19 & 17.63 & $15.8 \%$ \\
\hline $\mathbf{2 0 1 1}$ & 3.89 & 17.07 & $15.5 \%$ \\
\hline $\mathbf{2 0 1 2}$ & 3.82 & 16.81 & $14.0 \%$ \\
\hline $\mathbf{2 0 1 3}$ & 4.32 & 15.30 & $8.9 \%$ \\
\hline $\mathbf{2 0 1 4}$ & 4.60 & 15.76 & $12.5 \%$ \\
\hline $\mathbf{2 0 1 5}$ & 4.72 & 16.29 & $8.6 \%$ \\
\hline $\mathbf{2 0 1 6}$ & 5.07 & 14.88 & $12.0 \%$ \\
\hline $\mathbf{2 0 1 7}$ & 5.19 & 14.37 & $11.0 \%$ \\
\hline
\end{tabular}

Sumber : Laporan Keuamgan PT.Indofood Sukser Makmur Tbk 
JURNAL ILMIAH FEASIBLE: Bisnis, Kewirausahaan \& Koperasi, Vol.2.No.1 Februari 2020: 11-26

\section{Analisis Deskriptif}

Berdasarkan data yang diambil dari laporan keuangan PT.Indofood Sukses Makmur Tbk, dapat dilihat nilainya dari minimum, maksimum,rata rata (mean) dan standar deviasi dari masing-masing variabel penelitian dapat dilihat pada tabel sebagai berikut:

Tabel 1.5 Hasil Statistik Deskriptif

\begin{tabular}{|l|c|c|c|c|c|}
\hline & $\mathrm{N}$ & Min & Max & Mean & $\begin{array}{c}\text { Std. } \\
\text { Deviation }\end{array}$ \\
\hline $\begin{array}{l}\text { Perputaran } \\
\text { Kas }\end{array}$ & 9 & 3.82 & 8.49 & 5.0322 & 1.39522 \\
\hline $\begin{array}{l}\text { Perputaran } \\
\text { Piutang }\end{array}$ & 9 & 14.37 & 17.63 & 16.1922 & 1.18811 \\
\hline $\begin{array}{l}\text { Return On } \\
\text { Equity }\end{array}$ & 9 & 8.60 & 20.40 & 13.1889 & 3.72406 \\
\hline $\begin{array}{l}\text { Valid N } \\
\text { (listwise) }\end{array}$ & 9 & & & & \\
\hline
\end{tabular}

Berdasarkan hasil perhitungan pada tabel di atas dengan sampel pengamatan sebanyak 9 sampel. Perputaran kas mempunyai nilai minimum 3.82, maksimum 8.49, mean 5.0332 dan standar deviasi 1.39522. Perputaran piutang mempunyai nilai minimum 14.37, maksimum 17.63, mean 16.1922, dan standar deviasi 1.18811. Return on equity mempunyai nilai minimum 8.60, maksimum 20.40, mean 13.1889 dan standar deviasi 3.72046.

\section{Uji Asumsi Klasik}

\section{a. Uji Autokorelasi}

Menurut Santoso (2012), “tujuan uji autokorelasi adalah untuk mengetahui apakah dalam sebuah regesi linier ada korelasi antara kesalahan pengganggu pada periode $t$ dengan kesalahan pada periode t-1(sebelumnya). Prasyarat yang harus terpenuhi adalah tidak adanya autokorelasi dalam model regesi. Untuk mendeteksi gejala autokorelasi dapat menggunakan uji Durbin-Watson (DW). Pengambilan keputusan ada tidaknya autokorelasi dapat dilihat dari ketentuan berikut :

1) Jika o $<\mathrm{d}<\mathrm{dL}$, maka terjadi aurokorelasi positif.

2) Jika dL $<\mathrm{d}<\mathrm{dU}$, maka tidak ada kepastian terjadi autokorelasi atau tidak.

3) Jika d-dL $<\mathrm{d}<4$, maka terjadi autokorelasi negatif.

4) Jika 4-dU $<$ d $<4$-dL, maka tidak ada kepastian terjadi autokorelasi atau tidak.

5) Jika dU $<\mathrm{d}_{\neg}<4$-dU, maka tidak terjadi autokorelasi positif maupun negatif.

Tabel 1.6. Uji Autokorelasi

\begin{tabular}{cc|c|c} 
Model & $\mathrm{R}$ & $\begin{array}{c}\mathrm{R} \\
\text { Square }\end{array}$ & $\begin{array}{c}\text { Durbin- } \\
\text { Watson }\end{array}$ \\
\hline 1 & $.849^{\mathrm{a}}$ & .720 & 2.502 \\
\hline
\end{tabular}

Berdasarkan tabel 1.6 di atas nilai Durbin Watson (d)sebesar 2,502, dL 0,467 dan dU 1,896 pembanding menggunakan nilai signifikansi $5 \%$, jumlah sampel 9 (n), dan jumlah variabel independen $2 \quad(k=2)$, maka di tabel DurbinWatson akan didapat nilai dU sebesar 1,896 . Karena nilai DW 2,502 lebih besar dari batas atas (dU) 1,896 dan lebih besar dari $4-1,896=2,104$, atau d 2,502-dL o,476 < d 2,502 < 4. maka apat disimpulkan bahwa terdapat autokorelasi negatif. 
JURNAL ILMIAH FEASIBLE: Bisnis, Kewirausahaan \& Koperasi, Vol.2.No.1 Februari 2020: 11-26

\section{b. Uji Normalitas}

Untuk menguji normalitas menggunakan uji Uji KolmogorovSimimov

\begin{tabular}{|c|c|c|}
\hline \multicolumn{3}{|c|}{$\begin{array}{l}\text { Tabel 1.7. Kolmogorov-Simimov } \\
\text { One-Sample Kolmogorov-Smirnov Test }\end{array}$} \\
\hline \multicolumn{3}{|c|}{$\begin{array}{c}\text { Unstandardized } \\
\text { Residual }\end{array}$} \\
\hline & $\mathrm{N}$ & 9 \\
\hline \multirow{2}{*}{$\begin{array}{l}\text { Normal } \\
\text { Parameters }{ }^{a} \text {, }\end{array}$} & Mean & .0000000 \\
\hline & Std. Deviation & 1.96928579 \\
\hline \multirow{3}{*}{$\begin{array}{l}\text { Most } \\
\text { Extreme } \\
\text { Differences }\end{array}$} & Absolute & .237 \\
\hline & Positive & .157 \\
\hline & Negative & -.237 \\
\hline \multicolumn{2}{|l|}{ Test Statistic } & .237 \\
\hline \multicolumn{2}{|c|}{ Asymp. Sig. (2-tailed) } & $.156^{\circ}$ \\
\hline \multicolumn{3}{|c|}{ a. Test distribution is Normal. } \\
\hline \multicolumn{3}{|c|}{ b. Calculated from data. } \\
\hline
\end{tabular}

Dasar pengambilan keputusan sebagai berikut :

1. Jika probabilitasnya (nilai sig) $>0,05$ maka Ho berdistribusi normal

2. Jika probabilitasnya (nilai sig) $<0,05$ maka $\mathrm{H}_{3}$ tidak berdistribusi normal.

Keputusan:

Pada tabel di atas nilai sig $=0,156 c>0,05$ sehingga $\mathrm{H}_{3}$ diterima berarti data residul berdistribusi normal.

\section{c. Uji Heteroskedastisitas}

Dasar pengambilan keputusan pada uji heterokedastitas adalah:

1) Jika ada pola tertentu, seperti titik yang membenruk pol tertentu yang teratur (bergelombang, melebar kemudian menyempit), maka mengidikasiakan telah terjadi heterokedastisitas.

2) Jika tidak ada pola yang jelas, seperti titik-titik menyebar diatas dan dibawah angka o (nol) pada sumbu Y, maka tidak terjadi heterokedastistas. Hasil output SPSS versi 25 untuk pengujian heteroskedastisitas:

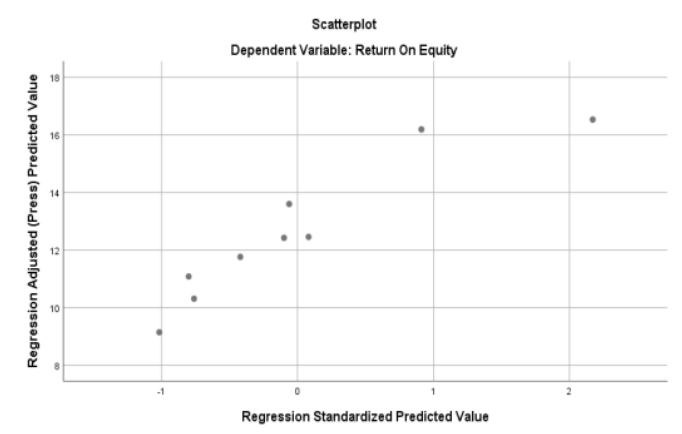

Gambar 1.1. Uji Heteroskedastisitas

Berdasarkan grafik hasil pengujian heteroskedastisitas bahwa titik-titik menyebar diatas dan dibawah angka o (nol) pada sumbu y serta membentuk pola tertentu, maka dapulkan disimpulkan bahwa tidak terdapat heterokedastisitas.

\section{d. Uji Multikolinearitas}

Uji Multikolinearitas bertujuann untuk mengetahui ada tidaknya multikolinearitas antara variabel-variabel independen. Model regresi yang terbaik seharunya tidak terjadi korelasi antara variabel independen. Dasar pengambilan keputusan uji multikolinearitas dapat dilakukan dengan dua cara nilai tolerance dan nilai VIF.

1) Jika nilai tolerace lebih besar dari 0,10 maka artinya tidak terjadi multikolinearitas terhadap data yang diuji.

2) Jika nilai tolerance lebih kecil dari 0.10 maka artinya terjadi multikolinearitas terhadap data yang diuji.

3) Selai itu dengan melihat nilai VIF, jika nilai VIF lebih kecil dari 10,oo maka 
JURNAL ILMIAH FEASIBLE: Bisnis, Kewirausahaan \& Koperasi, Vol.2.No.1 Februari 2020: 11-26

artinya tidak terjadi multikolenearitas

terhadap data yang diuji.

4) Jika nilai VIF lebih besar dari 10,00

maka artinya terjadi multikolienaritas

terhadap data yang diuji.

Nilai tolerance dan VIF dari variabelvariabel penelitian dapat dilihat pada tabel berikut ini:

Tabel 1.8. Uji Multikolinearitas

\begin{tabular}{|c|c|c|c|}
\hline & \multirow[b]{2}{*}{ Model } & \multicolumn{2}{|c|}{ Collinearity Statistics } \\
\hline & & Tolerance & VIF \\
\hline 1 & (Constant) & & \\
\hline & Perputaran Kas & .915 & 1093 \\
\hline & $\begin{array}{l}\text { Perputaran } \\
\text { Piutang }\end{array}$ & .915 & 1.093 \\
\hline
\end{tabular}

Berdasarkan nilai Tolerance perputaran kas \& perputaran piutang sebesar 0,915 dan VIF tabel di atas dapat dilihat bahwa variabel idependen dapat diketahui nilai VIF 1.093, maka dapat disimpulkan nilai tolerance $0,915>0,10$ artinya tidak terjadi multikolinearitas dan nilai VIF 1,093 < 10,0 artinya tidak terjadi multikolinearitas.

\section{Regresi Linier Sederhana}

a. Perputaran kas terhadap return on equity (ROE)

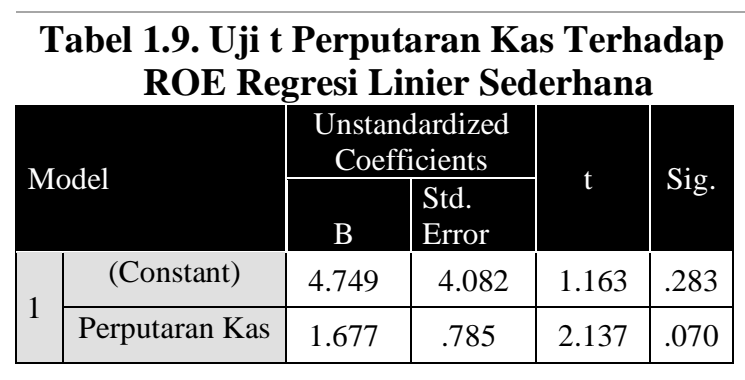

Dari hasil di atas diperoleh persamaan regresi tersebut adalah $\mathrm{Y}=4.749$ $+1.677 \mathrm{X}_{1}$

1) Angka konstanta sebesar 4.749. mempunyai arti jika ada perputaran kas
(X) maka nilai dari return on equity $(\mathrm{Y})$ adalah sebesar 4.749

2) Koefisien regresi perputaran kas sebesar 1.677 dan bertanda positif, menunjukan bahwa setiap kenaikan perputaran kas (X) satu persen maka return on asset $(\mathrm{Y})$ akan meningkat sebesar 1.677 dengan asumsi bahwa variabel bebas yang lain dari model regresi adalah tetap atau tidak mengalami perubahan.

Uji Hipotesis nilai $\mathrm{t}_{\text {hitung }} 2,137<\mathrm{t}_{\text {tabel; }}$ 2,306 dan signifikansi sebesar 0,070 > 0,05 dan nilai, sehingga dapat disimpulkan $H_{1}: \beta_{1}=\left(\mathrm{H}_{1}\right)$ ditolak yang berarti perputaran kas tidak berpengaruh signifikan terhadap return on asset perusahaan PT. Indofood Sukses Makmur Tbk.

b. Perputaran piutang terhadap return on equity (ROE)

Tabel 1.10. Uji t Perputaran Piutang Terhadap ROE

\begin{tabular}{|c|c|c|c|c|c|}
\hline \multirow{2}{*}{\multicolumn{2}{|c|}{ Model }} & \multicolumn{2}{|c|}{$\begin{array}{c}\text { Unstandardized } \\
\text { Coefficients }\end{array}$} & \multirow{2}{*}{$\mathrm{t}$} & \multirow{2}{*}{ Sig. } \\
\hline & & B & $\begin{array}{l}\text { Std. } \\
\text { Error }\end{array}$ & & \\
\hline \multirow[b]{2}{*}{1} & (Constant) & -23.811 & 13.162 & -1.809 & 113 \\
\hline & $\begin{array}{l}\text { Perputaran } \\
\text { Piutang }\end{array}$ & 2.285 & .811 & 2.818 & 026 \\
\hline
\end{tabular}

Dari tabel di atas diperoleh persamaan regresi $\mathrm{Y}=-23.811+2.285 \mathrm{X} 2$

1) Angka konstanta sebesar -23.811. mempunyai arti jika ada perputaran kas maka nilai dari return on equity adalah sebesar -23.811

2) Koefisien regresi perputaran piutang sebesar 2.285 dan bertanda positif, menunjukan bahwa setiap kenaikan 
JURNAL ILMIAH FEASIBLE: Bisnis, Kewirausahaan \& Koperasi, Vol.2.No.1 Februari 2020: 11-26

perputaran piutang satu persen maka return on equity akan meningkat sebesar 2.285 dengan asumsi variabel bebas yang lain dari model regresi adalah tetap atau tidak mengalami perubahan.

3) Uji Hipotesis nilai $t_{\text {hitung }} 2,818>t_{\text {tabe }}$; 2,306 dan nilai signifikansi sebesar $0,026<0,05$, sehingga dapat disimpulkan $H_{1}: \beta_{1}=\left(\mathrm{H}_{1}\right)$ diterima yang berarti perputaran piutang berpengaruh signifikan terhadap return on asset perusahaan PT. Indofood Sukses Makmur Tbk. yang berarti terdapat pengaruh variabel $\mathrm{X}$ variabel $\mathrm{Y}$.

\section{Koefisien Determinasi $\mathbf{R}$ Squere $\left(\mathbf{R}^{\mathbf{2}}\right)$}

Pengujian ini digunakan untuk mengetahui seberapa besar variabel idependen maupun menjelaskan pengaruh variabel dependen. Hasil uji determinasi seperti tabel berikut:

Tabel 1.11. Uji Koefisien Determinasi

\begin{tabular}{|c|c|c|c|}
\hline Model & $\mathbf{R}$ & R Square & $\begin{array}{c}\text { Adjusted R } \\
\text { Square }\end{array}$ \\
\hline 1 & $729^{a}$ & .531 & .465 \\
\hline
\end{tabular}

Berdasarkan tabel di atas menunjukkan bahwa nilai adjusted RSquare 0,531 atau $53,10 \%$. Artinya variabel independen berpengaruh terhadap varabel dependen sebesar $53,10 \%$ dan sisanya sebesar $46,90 \%$ dipengaruhi oleh variabel diluar penelitian ini.

\section{Regresi linier berganda}

Analisis regresi linier berganda digunakan untuk mengetahui adanya pengaruh atau hubungan secara bersamasama antara pengaruh perputaran kas dan perputaran piutang terhadap (variabel independent) terhadap return on equity (variabel dependent).

Tabel 1.12. Uji Analisis Regresi Linier Berganda

\begin{tabular}{|c|c|c|c|}
\hline Variabel & Koefisien & thitung & Sig. \\
\hline Konstanta & -23.189 & -2.111 & .079 \\
\hline Perputaran Kas & 1.213 & 2.013 & .091 \\
\hline $\begin{array}{l}\text { Perputaran } \\
\text { Piutang }\end{array}$ & 1.870 & 2.643 & .038 \\
\hline
\end{tabular}

Persamaan regresi linier berganda :

$\mathrm{ROE}=-23.189+(1.213)$ Perputaran_Kas + (o,1.870)Perputaran_Piutang

Keterangan :

Dari persamaan regresi linier berganda dapat diartikan sebagai berikut:

1) Konstanta sebesar -23.189 dapat diartikan bahwa Return On Equity akan bernilai -23.189 perputaran kas dan perputaran piutang bernilai o (nol) atau tidak ada.

2) Koefisien regresi perputaran kas sebesar 1.213 dan bertanda positif, ini menunjukan bahwa jika setiap kenaikan perputaran kas satu persen maka return on equity akan meningkat sebesar 1.213 dengan asumsi bahwa variabel bebas yang lain dari model regresi adalah tetap atau tidak mengalami perubahan.

3) Koefisien regresi variabel perputaran piutang sebesar 1.870 dan bertanda positif, ini menunjukan bahwa jika setiap kenaikan perputaran piutang satu persen maka return on equity maka naik sebesar 1.870 dengan asumsi bahwa variabel bebas yang lain dari 
model regresi adalah tetap atau tidak mengalami perubahan.

\section{Koefisien Korelasi dan Determinasi (R Square)}

Penguji ini digunakan untuk mengetahui seberapa besar variabel idependen maupun menjelaskan pengaruh variabel dependen. Nilainya berkisar o (nol) sampai dengan 1 (Satu). Apabila nilai R2 yang kecil maka kemampuan varibel-varibel dependen amat terbatas. Nilai yang mendekati 1 (satu) maka variasi variabel independen dapat memberikan hampir semua informasi yang dibutuhkan untuk memprediksi variabel dependen (Ghazali, 2011:97).

Tabel 1.13. Uji Koefisien Determinasi R Squere ( $\left.\mathbf{R}^{2}\right)$

\begin{tabular}{|c|c|c|c|}
\hline Model & $\mathbf{R}$ & R Square & $\begin{array}{c}\text { Adjusted R } \\
\text { Square }\end{array}$ \\
\hline 1 & $.849^{\mathrm{a}}$ & .720 & .627 \\
\hline
\end{tabular}

Berdasarkan hasil di atas menunjukkan bahwa nilai koefisien sebesar o,849 yang berarti tingkat keeratan tersebut sangat kuat. Sedangkan nilai adjusted $\mathrm{R}$ Square sebesar 0,720 atau $72,0 \%$ menunjukkan bahwa pengaruh variabel independent terhadap variabel dependen sebesar 72,0\% dan sisanya sebesar 28,0\% dipengaruhi oleh variabel diluar penelitian ini.

\section{Uji Hipotesis}

1. Uji t (Uji Parsial)

Pengujian ini gunakan untuk melihat pengaruh variabel Perputaran kas terhadap return on equity $(\mathrm{Y})$ dan Perputaran piutang terhadap return on equity (Y) dalam PT. Indofood Sukses Makmur Tbk. Ada[un kriteria pengujiannya:

a. Jika $t_{\text {hitung }}>\mathrm{t}_{\text {tabel }}$ maka variabel bebas berpengaruh terhadap variabel terikat.

b. Jika $\mathrm{t}_{\text {hitung }}<\mathrm{t}_{\text {tabel }}$ maka variabel bebas tidak berpengaruh terhadap variabel terikat.

Berikut hasil uji parsial seperti pada tabel 1.16.

Tabel 1.16. Hasil Uji Parsial

\begin{tabular}{|l|c|c|c|l|}
\hline $\begin{array}{l}\text { Variabel thitung } \\
\text { bebas }\end{array}$ & Sig & Ho & H1 \\
\hline $\begin{array}{l}\text { Perputaran } \\
\text { Kas }\end{array}$ & 2.013 & .091 & Diterima & Ditolak \\
\hline $\begin{array}{l}\text { Perputaran } \\
\text { Piutang }\end{array}$ & 2.643 & .038 & Ditolak & Diterima \\
\hline
\end{tabular}

a. Uji Hipotesis $H_{1}: P_{1} \neq$ dan $H_{a}: P_{1}=\left(\mathrm{H}_{\mathrm{o}}\right.$ dan $\mathrm{H}_{1}$ )

Berdasarkan pengujian di atas diketahui sig. untuk variabel $\mathrm{X}_{1}$ terhadap $\mathrm{Y}$ adalah sebesar 0,091 > 0,05 dan nilai $\mathrm{t}$ hitung $2,013<\mathrm{t}$ tabel 2,447, sehingga dapat disimpulkan $H_{1}: \beta_{1}=\left(\mathrm{H}_{1}\right)$ ditolak yang berarti tidak terdapat pengaruh perputaran kas terhadap return on equity pada PT. Indofood Sukses Makmur Tbk.

b. Uji Hipotesis $H_{0}: \beta_{2} \neq$ dan $H_{0}: \beta_{2}=\left(\mathrm{H}_{\mathrm{o}}\right.$ dan $\mathrm{H}_{2}$ )

Diketahui sig. untuk variabel $\mathrm{X}_{2}$ terhadap Y adalah sebesar 0,038 < 0,05 dan nilai $t$ hitung 2,643 $>\mathrm{t}_{\text {tabel }}$ 2,365, sehingga dapat disimpulkan $H_{0}: \beta_{2}=\left(\mathrm{H}_{2}\right)$ diterima yang berarti terdapat pengaruh positif perputaran piutang terhadap return on 
JURNAL ILMIAH FEASIBLE: Bisnis, Kewirausahaan \& Koperasi, Vol.2.No.1 Februari 2020: 11-26

equity (Y) pada PT. Indofood Sukses Makmur Tbk.

2. Uji f (Uji Simultan)

Uji simultan diperlukan mengetahui apakah semua variabel independen yang dimasukkan dalam model mempunyai pengaruh secara simultan terhadap variabel dependen. Dasar pengambikan keputusan uji F sebagai berikut:

a. Jika profitabilitas nilai $\mathrm{F}_{\text {hitung }}<\mathrm{F}_{\text {tabel }}$ atau signifikansi < 0,05, maka dapat dikatakan bahwa tidak ada pengaruh antara variabel independen secara bersama-sama terhadap variabel dependen.

b. Jika profitabilitas nilai $\mathrm{F}_{\text {hitung }}>\mathrm{F}_{\text {tabel }}$ atau signifikansi > 0,05, maka dapat dikatakan bahwa tidak ada pengaruh antara variabel independen secara bersama-sama terhadap variabel dependen.

Berikut hasil pengujian simultan (Uji F)

Tabel 1.17. Hasil Uji Simultan/Kelayakan Model (Uji F)

\begin{tabular}{|l|c|c|c|c|}
\hline Fitung & \multicolumn{2}{|c|}{ F $_{\text {tabel }}$ Sig } & Ho & H1 \\
\hline 7,728 & 5,14 & $0,022^{\mathrm{b}}$ & Ditolak & Diterima \\
\hline
\end{tabular}

Uji Hipotesis $H_{0}: \beta_{3} \neq$ dan $H_{0}: \beta_{3}=\left(\mathrm{H}_{\mathrm{o}}\right.$ dan $\mathrm{H}_{3}$ )

Berdasarkan pengujian diatas diketahui nilai sig, pengaruh perputaran kas dan perputaran piutang secara simultan terhadap return on equity adalah sebesar $0,022^{\mathrm{b}}<0,05$ dan nilai $\mathrm{f}_{\text {hitung }} 7,728>\mathrm{f}_{\text {tabel }}$ 5,14, sehingga dapat di simpulkan bahwa $H_{0}: \beta_{3}=\left(\mathrm{H}_{3}\right)$ diterima yang berarti secara simultan terdapat pengaruh perputaran kas dan perputaran piutang terhadap return on equity pada PT. Indofood Sukses Makmur Tbk.

\section{Pembahasan}

\section{Pengaruh Perputaran Kas Terhadap Return on Equity (ROE)}

Berdasarkan pengujian secara parsial dalam uji regresi linier dapat dilihat nilai sig. untuk variabel perputaran kas (X1) terhadap return on equity (Y) Pada PT. Indofood Sukses Makmur Tbk, adalah sebesar 0,079 > 0,05 dan nilai $t$ hitung 2,013 < t tabel 2,447, sehingga dapat dilihat nilai signifikasi lebih besar dari $5 \%$. Koefisien regresi yang dihasilkan 1.213 bernilai positif. Dengan demikian kesimpulan pengujian tersebut dapat dimpulkan bahwa secara parsial perputaran kas tidak berpengaruh signifikan terhadap return on equity (ROE).

Hasil penelitian yang tidak signifikan ini kemungkinan besar diakibatkan kecilnya persentase return on equity pada tahun 2013 dan 2015, sehingga tidak biasa mendukung persentase return on equity tahun lainnya. Kecilnya persentase return on equity pada 2013 dan 2015 diakbibatkan besarnya pembiayaan beban bunga yang dibayarkan pada tahun 2013 dan 2015.

Penelitian ini sejalan dengan Ayu Eka Pangesti (2013) dengan judul pengaruh perputaran kas, perputaran piutang dan perputaran persediaan terhadap profitabilitas yang mengatakan 
JURNAL ILMIAH FEASIBLE: Bisnis, Kewirausahaan \& Koperasi, Vol.2.No.1 Februari 2020: 11-26

perputan kas tidak berpengaruh signifikan terhadap profitabilitas.

\section{Pengaruh Perputaran Piutang Terhadap Return on Equity (ROE)}

Berdasarkan hasil pengujian secara parsial dalam uji regresi linier dapat dilihat nilai sig. untuk variabel perputaran piutang (X2) terhadap return on equity $(\mathrm{Y})$ Pada PT. Indofood Sukses Makmur Tbk, adalah sebesar $0,038<0,05$ dan nilai t hitung 2,643 $>$ t tabel 2,365, sehingga dapat dilihat nilai signifikasi lebih kecil dari 5\%. Koefisien regresi yang dihasilkan 1.870 benilai positif. Dengan demikian kesimpulan pengujian tersebur adalah bahwa secara parsial perputan piutang berpengaruh signifikan terhadap return on equity (ROE).

Hasil ini sejalan dengan peneliti Irman Deni (2014), Merin Widasari (2016), Eka Ayu Rahayu dan Joni Susilowibowo (2014) dan Tutri Indraswari (2018) yang bersama sama mengatakan bahwa perputaran piutang berpengaruh secara signifikan terhadap profitabilitas

\section{Pengaruh Perputan Kas dan Perputan Piutang terhadap Return on Equity (ROE)}

Untuk pengujian seca simultan dapat dilihat bahwa nilai sig, untuk pengaruh perputaran kas (X1) dan perputaran piutang (X2) secara simultan terhadap Y Pada PT. Indofood Sukses
Makmur Tbk, adalah sebesar o,o22b < o,05 dan nilai f hitung 7,728 > f tabel 5,14 ,berarti nilai signifikasi dengan 5\%. Koefisien konstanta $-\mathbf{2 3 , 1 8 9}$ bernilai negatif. Kesimpulan dari pengujian tersebut menunjukkan bahwa secara simultan perputan kas dan perputaran piutang memiliki pengaruh yang signifikan terhadap return on equity (ROE).

Hasil Penelitian ini sejalan dengan Irman Deni (2014), Eka Ayu Rahayu dan Joni Susilowibowo (2014), Ayu Eka Pangesti (2013), dan Tutri Indraswari (2018) perputaran kas dan perputan piutang berpengaruh signifikan terhadap profitabilitas.

Tingkat pengaruh variabel indevenden atau bebas (perputaran kas dan perputaran piutang) terhadap variabel devenden atau terikat (Return on Equity) adalah sebesar $72 \%$ dan sisanya $28 \%$ dipengaruhi variabel lain diluar variabel yang digunakan dalam penelitian ini.

\section{SIMPULAN}

\section{Kesimpulan}

1. Secara parsial perputaran kas tidak berpengaruh signifikan terhadap return on equity pada PT. Indofood Sukses Makmur Tbk. Dibuktikan dengan hasil nilai $t_{\text {hitung }} 2,013<t_{\text {tabel }} 2,447$ dengan signifikansi sebesar 0,079 > 0,05.

2. Secara parsial perputaran piutang berpengaruh signifikan terhadap return on equity pada PT. Indofood Sukses 
Makmur Tbk. Dibuktikan dengan hasil nilai $t_{\text {hitung }} 2,643<t_{\text {tabel }} 2,365$ dengan signifikansi sebesar 0,038 > 0,05.

3. Secara Simultan perputaran kas dan perputaran piutang berpengaruh signifikan terhadap return on equity Pada PT. Indofood Sukses Makmur Tbk. Dibuktikan dengan persamaan regresi linier berganda $\mathrm{ROE}=-23.189+(1.213)$ Perputaran_Kas+ (0,1.870) Perputaran_Piutang, hasil $\mathrm{F}_{\text {hitung }}$ 7,728 $>\mathrm{F}_{\text {tabel }}$ 5,14 dan signifikan sebesar 0,022 < 0,05 .

\section{Saran}

Berdasarkan hasil penelitian yang telah dilakukan, maka saran yang yang dapat disampaikan:

1. Manajemen perusahaan harus mempertimbangkan kemampuam perusahaan dalam mengelola kasnya dengan baik, ahar tidak terjadi lagi perputaran kas yang sangat rendah pada tahun 2012 yaiutu 3,82 kali, dan meningkatkan kembali perputaran kasnya seperti pada tahun 2009 yaitu 8,49 kali.

2. Perputaran piutang juga harus di kelola dengan efisien dan efektif sehingga dapat memiliki tingkat profitabilitas yang baik seperti tahun 2009 yaitu dengan perputaran piutang 17,77 kali yang dapat menghasilkan laba yang maksimal.

3. Perusahaan juga harus tetap meningkatkan kinerja karyawannya agar dapat bekerja dengan maksimal ,efisien dan efektif sehingga dapat mencapai tujuan perusahaan yang telah dibuat.

\section{DAFTAR PUSTAKA}

Ghozali, I. (2011). Aplikasi Analisis Multivariate Dengan Program SPSS. Semarang: Universitas Diponegoro.

Hanafi dan Halim. (2011). Analisis Laporan Keuangan", Edisi Keempat. Yogyakarta: UPP STIM YKPN.

Harahap. (2010). Analisis Kritis Atas Laporan Keuangan. Jakarta: Rajagrafindo Persada,

Hery. (2013). Auditing Pemeriksaan Akutansi, Cetakan Pertama. Jakarta: Center of Academic Publishing Service (CAPS).

Iqbal, H. (2006). Analisis Data Penelitian Dengan Statistik. Jakarta: Bumi Aksara.

Kasmir. (2015). Analisis Laporan Keuangan, Edisi Kesatu, Cetakan Kedelapan. Jakarta: Raja Grafindo Persada.

Keuangan. Jakarta: Raja Grafindo Persada.

Riyanto, B. (2011). Dasar-Dasar Pengambilan Keputusan Perusahaan. Yogyakarta: BPFE.

Sugiyono. (2005). Statistika Untuk Penelitian. Bandung: Alfabeta. 
, (2011). Metode Penelitian

Kuantitatif Kualitatif dan $R \& D$.

Bandung: Alfabeta. , (2012). Metode Penelitian

Kuantitatif Kualitatif dan $R \& D$.

Bandung: Alfabeta.

, (2014). Metode Penelitian

Kuantitatif Kualitatif dan $R \& D$.

Bandung: Alfabeta.

Surhayadi dan Purwanto. (2004). Statistika

Dasar. Jakarta: Salemba Empat.

Sutrisno. (2012). Manajemen Keuangan

Teori,Konsep dan Aplikasi. Jakarta:

Ekonisia.

Wild, Subramanyan dan Hasley (2005). Analisis Laporan Keuangan, Edisis Delapan, Buku Kesatu. Jakarta:

Salemba Empat. 